\title{
Mucocutaneous venous malformations
}

INSERM

\section{Source}

INSERM. (1999). Orphanet: an online rare disease and orphan drug data base.

Mucocutaneous venous malformations. ORPHA:2451

Mucocutaneous venous malformations (VMCMs) are hereditary vascular malformations characterized by the presence of small, multifocal, bluish-purple venous lesions involving the skin and mucosa. 